\title{
Refugees from Inside the System: Iraqi Divorcees in Jordan
}

\author{
Susan MacDougall
}

\begin{abstract}
Based on fieldwork with Iraqi women who married and then divorced Jordanian men and are now registered refugees in Jordan, this study explores the relationship between marriage and immigration laws and refugee status for Iraqis in the country. The legal systems effectively fence the divorced women in, with child custody laws preventing them from leaving and citizenship laws preventing them from securing long-term residency. Jordan's citizenship and immigration laws collude with family law traditions that assume women's dependence on their husbands to magnify divorced Iraqi women's social exclusion. As Iraqi refugees extend their stays in the country, Jordan's "guests" and their needs have become part of the domestic social landscape; structural refusal to acknowledge their presence contributes to their isolation and invisibility. This case suggests that citizenship laws that differentiate between men and women create gendered refugees as well as gendered citizens.
\end{abstract}

\section{Résumé}

Cet article repose sur une étude de terrain effectuée auprès de femmes irakiennes qui se sont mariées avec des Jordaniens, qui se sont ensuite divorcées, et qui sont maintenant enregistrées en Jordanie en tant que réfugiées. L'article explore les relations entre les lois du mariage et de l'immigration et le statut de réfugié dans le cas de ces Irakiennes. Le système légal jordanien limite effectivement les femmes divorcées, puisque les lois sur la garde des enfants les empêchent de quitter la Jordanie, tandis que les lois sur l'immigration et la citoyenneté les empêchent d'obtenir un droit de résidence à long terme. Ces lois jordaniennes sur l'immigration et la citoyenneté fusionnent avec la tradition des lois sur la famille impliquant la dépendance de la femme envers son mari, et ainsi renforcent l'exclusion sociale des femmes irakiennes divorcées. Alors que les réfugiés irakiens prolongent leur séjour en Jordanie, ces visiteurs et leurs besoins spécifiques deviennent une partie constituante du paysage social du pays. Toutefois, le refus structurel de prendre en compte leur présence contribue à leur isolement et leur invisibilité. Cette problématique suggère que les lois sur la citoyenneté faisant la différence entre les hommes et les femmes créent des catégories différentes de réfugiés basées sur le sexe, tout comme elles créent des catégories différentes de citoyens basées sur le sexe.

\section{Universally Different: The Refugee in the Eyes of the State}

In 1943, Hannah Arendt described the refugee experience as one of confusion. "The less we are free to decide who we are and to live as we like, the more we try to put up a front, to hide the facts, and to play roles ... It is the same story all over the world, again and again," she wrote. ${ }^{1}$ Her writing addresses the experiences of European Jews displaced in World War II, but her observations are relevant for many current accounts of the upheaval that refugees experience.

Studies that focus on refugees' experiences also show that displacement demands adaptations in numerous facets of social life, and that this process has an emotional dimension. ${ }^{2}$ The "same story" that Arendt refers to is not that which precedes displacement, but that which follows it: the individual being plunged into an unfamiliar environment that then shapes her way of life. Arendt argues that simply being labelled a refugee implies that other identifying details will be relegated to the background, both to the institutions charged with managing refugees and, consequently, for the displaced person himself as he goes about constructing normalcy in a new place. While this generalization makes 
it easier for host societies to regulate the refugee and his brethren, it can make it more difficult to integrate into the host society.

The nature of the regulations is different in every context, though, and while the progression of the story may be the same across locations, local policies define refugee com munities in different ways and thus enable different sorts of livelihoods. Liisa Malkki made this fact very apparent in her comparison between Hutu "camp refugees" and "town refugees" in Tanzania, which told the story of two discrete communities with different experiences of life after displacement. Camp refugees, who lived in a secluded area just for displaced people located outside of the city of Kigoma, formed a tight-knit community within its confines and developed narratives explaining Hutu purity and separateness. Town refugees lived among the Tanzanian residents of Kigoma and had the freedom to move about the city, and Malkki found their narratives reflected their varied circumstances in Kigoma rather than a cohesive group narrative like that of the camp residents.

Laws and policies set the terms of refugees' acclimation, and they have the potential to alter refugee communities' and host communities' view of their place in society. ${ }^{3}$ While political violence in home countries causes displacement, one does not become a refugee until he or she arrives in the place of refuge, the confines of which shape each person's experience. ${ }^{4}$ It is the host country reception of refugees that concerns me here, specifically the influence of the paradigm of a refugee that host countries employ on the experiences of those who do not fit within that model.

The modern state has wide-ranging power to influence through regulation, and it approaches the management of refugees through more than one channel. When an individual seeks services as a refugee, her identity, personal story, and physical health are all subject to interrogation by Western asylum-granting nations, and by intergovernmental agencies like the International Organization for Migration (IOM) and the United Nations High Commissioner for Refugees (UNHCR). Those seeking resettlement are required to demonstrate the truth of their accounts, ${ }^{5}$ and they undergo numerous interviews, psychological assessments, and medical examinations before receiving it. ${ }^{6}$ Aihwa Ong has pointed out that the social and procedural means by which immigrants are incorporated into receiving societies actively place them in existing social categories. $^{7}$ In the case of those enduring forced displacement, the homogenizing "minority" status in question is that of refugee-which can be produced through the assignment of status, such as that granted by the United Nations, and is also implied through the presence of special services for people to access. While citizenship anticipates differences in gender, class, and ethnicity, refugee-ness is primarily predicated on two statuses that inspire opposing responses: that of "victim,"8 which entitles refugees to assistance, and that of the non-citizen, ${ }^{9}$ which restricts them to certain kinds of entitlements.

The notion of citizenship and the notion of the refugee are in some ways mutually reliant, to the extent that the nation-state system posits insiders and outsiders. ${ }^{10}$ Collier and Ong noted, though, that while citizenship remains the most direct means of accessing rights, it has been unbundled in certain contexts, with refugee status and its associated entitlements one example of a partial rights-granting status. ${ }^{11}$ Nations now offer incomplete rights "packages" to people who are displaced, ill, or economically desirable skilled workers; the logic employed to distribute quasi-citizenship destabilizes the original concept as systems adapt to include not just a nation of people but everybody, at least in theory. Refugee status protects people whose citizenship does not entitle them to protection, either because their government cannot help them or because it will not, and offers one avenue toward accessing an approximation of citizens' rights.

Citizens' rights, of course, are context-dependent and often differentiate between male and female citizens. Suad Joseph refers to the production of citizens as a "cultural process of subjectification," the content of which is substantially imbued with gender difference. ${ }^{12}$ Both juridical processes and rhetorical notions of the ideal citizen give primacy to the male ideal of a citizen, with females as their complement. Valentine Moghadam points out that the gendering of citizenship is also not purely a domestic project, and within the Middle East, where debates on the modern versus the traditionally Islamic are ongoing, roles for women are conceived as a means of declaring alignment with one perspective or the other. ${ }^{13}$ It is important to understand these debates about the appropriate nature of womanhood in light of the role colonizing interests played in depicting Islamic practices such as veiling as uncivilized, thus assigning women an outsized role in the project of creating a national identity. ${ }^{14}$ Across the Middle East, citizenship is reliant on local or national notions of gender, and the rights and responsibilities of female citizenship might differ substantially from male.

In this paper, I will discuss the experiences of Iraqi women living in Jordan who were formerly married to Jordanians, and now are divorced and registered refugees with UNHCR, to make the argument that the narrowness of the "refugee" label ignores the diversity of circumstances that characterize Iraqis' lives in Jordan. Since the paths to legal residence available to Iraqis are typically costly, those that cannot afford them are funnelled into the international 
refugee management apparatus, which is ill-suited to meeting their needs. ${ }^{15}$

\section{Methodology}

Research for this paper was conducted in Amman, Jordan, between December 2010 and September 2011. During this period I taught two different English classes for Iraqis in East Amman, the lower-income counterpart to more affluent West Amman, and was a volunteer teacher at a community centre that offered kindergarten classes for Iraqi children as well as lectures and discussion groups for Iraqi mothers. I also conducted interviews with NGO directors who were providing services to Iraqis. My intended focus was the relationship between Jordanian law and Iraqi family life in Jordan, and intermarriage between Iraqis and Jordanians emerged as a facet of this topic meriting further exploration. This paper is the result of a series of interviews I conducted with four different Iraqi women who had married Jordanians and subsequently divorced, and quotes are taken from those interviews, though my work with Iraqis in the other above-mentioned contexts also informs the analysis. Two of the women I interviewed were introduced to me by students in my English classes, which were coordinated by a neighbourhood organization offering minimal grants of food and cash assistance, and two through an NGO that provided legal services. I learned subsequently that all four of them were aware of both organizations, and had been in touch with them to request services at different points.

Being introduced to people through the organizations that offer them services added an interesting dimension to my research. Initially, I often found that people-including the divorced women that I interviewed, as well as others that I met through different channels-assumed that my association with the charities meant that I had services to offer. When it became apparent that, other than occasional small gifts of fruit or sweets, I had little to give, the relationship was reversed and they emerged as the ones meant to be helping me. As a young woman living alone in a foreign country, I was perceived as needing guidance and advice, and as people transitioned from seeing me as service provider to care recipient, they shared additional details about themselves, some of them contradicting earlier revelations. I came to see this feature of the work as another instance of the layers of truth and interpretation accompanying fieldwork, ${ }^{16}$ particularly in the Middle East, ${ }^{17}$ though ongoing engagement on the importance of truth to the refugee experience ${ }^{18}$ suggest that this facet merits further engagement.

The fact that all four of these women had arrived in Jordan prior to 2003, and registered as refugees after, ostensibly leaves them out of the widely covered Iraqi refugee "crisis" of 2006 and 2007. ${ }^{19}$ Instead, they fit into a longerterm pattern of migration from Iraq into Jordan, and it is the contradiction and insecurity of their experience seeking services as refugees from UNHCR and other NGOs while remaining without a legal status in Jordan that this paper will discuss. ${ }^{20}$

\section{Of Fences and Neighbours: Laws, Borders, Refugees, and Guests}

The Iraqi divorcees I worked with live a fenced-in life in Jordan, with a myriad of social and political factors limiting their choices. An Iraqi wife cannot obtain Jordanian citizenship before three years of marriage, and should a marriage not last long enough for citizenship then seeking refugee status through UNHCR is a logical alternative. The long-term solution that it offers envisions a person using Jordan merely as a place of transit, which is not the case for women who have lived in the country for over a decade and have children with Jordanian citizenship. While Iraqis' interactions with official agencies in Jordan turn on their non-citizen status, the divorced women with whom I worked are similarly excluded by organizations whose mandate is to serve Iraqis.

While the extenuating circumstances of Iraq in the present play an important role in shaping Iraqis' experiences of Jordan, their position within the social landscape is one with many layers in the history of migration into the country from Iraq and elsewhere in the region. In particular, the Palestinian presence in the country has been a defining part of Jordanian history and political strategy for nearly as long as it has been a country; Jordan became an independent state in 1946, and the politics of Palestinian refugees and their integration were a preoccupation from the outset. After the establishment of Israel in 1948 and Jordan's annexation of the West Bank, the population of Jordan grew rapidly to 1.5 million, with fewer than 500,000 Jordanians, and all West Bank Palestinians were offered Jordanian citizenship. ${ }^{21}$ The question of Jordanian government and society's precise relationships to the Palestinian population then became a sensitive issue, and continues to be politically sensitive. Joseph Massad argues in an investigation of Jordan's laws and legal history, that the Palestinian question's ongoing relevance shaped the government's approach to constructing a Jordanian nationalism, with citizenship and immigration law that differentiated between the groups an important feature of these efforts. The persistent felt need to demonstrate a difference between Jordan and Palestine meant that, following the initial openness toward citizenship, distinctions were maintained between the two groups despite the fact that over half of Jordan's residents were Palestinian. Separating out Jordanians by whatever 
means was a way of engendering nationalism in the absence of existing sentiments. ${ }^{22}$ Laws contributed to the making of the new nation by restricting the right to pass on citizenship to men and by placing stringent restrictions on foreigners' acquisition of a Jordanian passport. The originally conceived citizenship laws, which drew substantially on British legal code as it was in the 1920s and 30s, dovetailed with Islamic legal codes for inheritance and marriage to create a separate category of female citizen, which imbued "Jordanian-ness" with values and content. ${ }^{23}$ This initial conception of the "Palestinian Other", Massad argues, contributed to the ongoing view of refugees and displaced peoplewhich often rhetorically includes West Bankers who either had or received citizenship - as threatening Jordan's territorial sovereignty.

Massad draws on Foucault's work on governmentality to argue that citizenship laws and nationalism enable one another: once the laws define a group of "citizens" and a group of "non-citizens," nationalism has an opportunity to take root. ${ }^{24}$ The citizen does not exist as such until the laws clarify who a citizen is, after which everyone in the country either falls into the citizen category or outside it and fulfills his or her role as insider or outsider. In the Jordanian case, the opposing "refugee" category was present to contrast the emerging notion of citizenship from the early days of the nation; the Other of the Palestinian provided contrast against which Jordanian identity could take shape.

The nature of the Palestinian question in Jordan has given the term "refugee" a specific association with the Palestinian population, and until recently, the word "refugee" was little used to describe Iraqis in the country, either socially or legally. ${ }^{25}$ Iraqis' presence in Jordan is hardly new, however. Faisal II, the last king of Iraq, was a cousin of Jordan's King Hussein; following Faisal's assassination in 1958, King Hussein later became a close counterpart of Saddam Hussein until the former's death in 1999. Jordan and Iraq maintained close, albeit sometimes strained, political relations from the days of Iraq's Hashemite monarchy through the sanctions period from 1990 to 2003, permitting cultural exchange and continuous multi-directional migration. ${ }^{26}$ The comprehensive international sanctions imposed by the United Nations in 1990 severely restricted the flow of goods into and out of Iraq, first to encourage it to withdraw troops from Kuwait and later to prevent any further military action. The sanctions had a devastating effect on Iraqi economy and society, with an estimated 20 percent of Iraqis living in extreme poverty by $1998 .{ }^{27}$ In 1997-well before the 2003 war-an estimated 60,000 Iraqis were living in Jordan. ${ }^{28}$ Social ties, as well as perceived differences, between the two groups have deeper roots than the "refugee crisis" rhetoric implies.
Iraqis continue to come to Jordan for a myriad of reasons: to visit relatives, to work, to do art, to transit in and out of Iraq, and to follow their spouses; ${ }^{29}$ they also continue returning to Iraq, when they are able, to see family, evaluate the security situation, or to check on property. ${ }^{30}$ Géraldine Chatelard argues that highly visible large-scale displacement post-2003 has eclipsed the role that prior migration played in establishing patterns that Iraqi movement in and out of Jordan continues to follow. ${ }^{31}$ For all these reasons, a strategy that offers only the options of resettlement or return is an ill-fitting solution to the more complicated cases of women whose parents are Iraqi but who have Jordanian children.

\section{Jordan's Iraqi Community, Past and Present}

A brief look at the status of Iraqis in Jordan, past and present, makes clear the confusions inherent in discussions of "Iraqi refugees." Despite the high visibility of the Iraqi refugee issue, accurate counts of their number in Jordan remain a topic of some contention, ${ }^{32}$ and the circumstances of the four women whose stories I share here highlight the importance of Jordan as a safe haven for those who have developed strong ties within the country over the past several decades. The women's experiences not fitting properly into either the "guest" or the "refugee" category demonstrate the confusion that has arisen through Jordan's reluctance to explicitly address the needs of a population that has been using it as a second home for some time.

The four women who participated in this research followed similar trajectories, arriving in Jordan during the late 1990s or early 2000s, before the war in 2003, and divorcing after having children without gaining citizenship. Two were married in Iraq and came into Jordan with their husbands, and two came with their families and were married in Amman. Though they have registered for resettlement, the fact that their children are Jordanians with citizenship and extended family in the country makes them both unlikely and unenthusiastic candidates for third-country resettlement. Though conditions continue to improve in Iraq, return is not yet entirely safe. ${ }^{33}$ Jordanian policy also permits fathers to block their children's departure from the country with their mother, making exit difficult in some cases. ${ }^{34}$ At the same time, their socially and economically vulnerable positions in Jordan mean that they have to seek assistance where it is available, and registering with the United Nations legitimizes their residence in the absence of a permit and in some cases gives them access to monthly cash assistance. ${ }^{35}$ Jordanian marriage law, regional migration history, and gendered policies act together to keep them isolated and economically vulnerable, which increases their need to draw on the internationally sponsored services in place. 
While popular media accounts tend to depict displaced Iraqis as having fled sectarian violence in their country following its uptick after $2006,{ }^{36}$ this represents only one trajectory through which Iraqis have arrived in Jordan. Many arrived during the 1990 s and earlier ${ }^{37}$ - making the rapidity suggested by the term "refugee crisis" a less accurate description of their case. The 1951 Convention on the Status of Refugees, which guides UNHCR's and signatory countries' policies toward refugees, operates under the ostensibly straightforward mandate of protecting displaced people from a "well-founded fear of persecution" in their home country. ${ }^{38}$ UNHCR offers protection, assistance, and coordination of their resettlement, repatriation, or integration to the host country; its mandate in Jordan is based on the understanding that refugees will not be residing in Jordan long-term. ${ }^{39}$ Jordan is not a signatory to the 1951 Convention or the 1967 Protocol, and provides only limited rights and benefits for refugees. Asylum-seeker or refugee status does not in itself give Iraqis the right to seek employment in Jordan, leaving many either unemployed or working illegally. ${ }^{40}$ With a 13.1 percent unemployment rate for Jordanians, competition for work is high and wages are low already. ${ }^{41}$ Long-term residence in Jordan does not seem sustainable for those who cannot secure work, making resettlement in a third country a sought-after option for Iraqis despite the fact that it is infrequently granted. ${ }^{42}$

Though some Iraqis who were living outside the country have returned, a lack of appealing opportunities for work and stagnation in job creation and employment discourage people from going back. According to World Bank data from 2010, only 38 percent of Iraqi adults were working due to the absence of jobs and the minimal financial benefits they brought. ${ }^{43}$ Baghdad's infrastructure has suffered from years of conflict and inattention, and frequent power outages and trouble accessing clean drinking water contribute to the oppressive conditions in the city; areas outside the capital offer even fewer comforts. ${ }^{44}$ Ongoing concerns about the security situation in addition to these other disincentives to relocation make Jordan more appealing, at least for the time being. With neither return nor resettlement viable options, Iraqi divorcees-along with many others-piece together those bits of support available to them in Jordan.

Divorced women represent a mere 0.8 percent of Iraq's population, and 10 percent of households are femaleheaded. ${ }^{45}$ In Jordan, according to the most recent data available, 11 percent of households are female-headed, ${ }^{46}$ though since that statistic was published in 2006, the rate of divorce has been increasing ${ }^{47}$ and is an active topic for public debate. ${ }^{48}$ In both countries, however, female-headed households as well as divorcees represent a minority of cases.
For the women with whom I worked, their Iraqi citizenship entitled them to support for refugees that, had they been Arab women of another nationality divorced by Jordanian men, would not have been available. Their marital status and economic situation were as much a cause of their vulnerability as the political situation in Iraq. The 70 JOD (about \$100) monthly cash assistance that UNHCR was providing at the time this research was conducted offers a financial lifeline. The years of waiting that the resettlement process often entails in fact made it a more attractive option, as it let them receive bits of aid without the threat of being transferred out of the country. While the services offered by UNHCR serve to tide them over in the present, the roots of their path into the refugee system extend back before the 2003 war.

\section{Marriage as Refuge: Marriage and Migration in Iraq and the Arab World}

By 2003, developments unfavourable to Iraqi women marrying Jordanians had been in motion for several years. Examining these trends reveals entrenched disadvantages for this group of women growing from intertwined systems of marriage, immigration, and social trends. The gendered features of citizenship addressed in the introduction are apparent in the Jordanian context in two ways that significantly affect women's rights in a marriage. First, citizenship is restricted to the patriline, meaning that children are born to the father's nationality, and Jordanian women are not entitled to pass on their citizenship. This privileging of the male right to lineage is not unique to Jordan, and has its roots in the use of Islamic law to create legal codes that buttressed existing nationalist agendas. ${ }^{49}$ In Jordan, it is also seen as discouraging marriages between Jordanian women and foreigners, with non-citizen Palestinians included in that category. ${ }^{50}$ In addition to discriminatory policies on citizenship, Jordan's personal status law for Muslims also includes the disincentives to divorce that characterize Islamic legal systems, ${ }^{51}$ wherein it is easy for men to initiate divorce and difficult for women to contest it. Limited rights for wives make Iraqi brides vulnerable initially, and if they divorce before they acquire citizenship then they remain in the country as foreigners. Islamic inheritance laws, which afford male kin twice the shares of females, have in the past been correlated with endogamy; ${ }^{52}$ additionally, "close" marriages are considered a safer choice, a preference reflected in the continued-though declining-presence of marriages between first or distant cousins. ${ }^{53}$

The combination of preferential legal treatment in citizenship laws, marriage contracts, and wealth distribution means Jordanian husbands enjoy much more legal power in marriage than their wives. They inherit more wealth, have 
the right and ability to acquire passports for their children and family, and absent specific stipulations to the marriage contract can decree divorce at will. The laws keeping family wealth out of women's hands-daughters inherit half their brothers' share of a deceased father's wealth, and widows with children take one-eighth of a deceased husband's estate-incentivize families to keep their daughters close to home and to be wary of brides from outside. All of these factors put Iraqi women marrying Jordanians in a vulnerable position legally and socially.

These policies have developed over years of nation-building efforts, ${ }^{54}$ in which debates on the proper place of women play an important role, ${ }^{55}$ in the context of Jordan's regional economic interdependence ${ }^{56}$ and migration flows both into and out of the country. ${ }^{57}$ Jordan's position in regional migration streams has led to outsiders from around the region coming almost continuously since 1948. Regional migration follows numerous patterns, and Jordan is a destination for both refugees (Iraqis, Palestinians, Lebanese during the 2006 war and, at present, Syrians) and economic migrants from less developed countries, such as Egypt. ${ }^{58}$ Home to some of the region's best hospitals and a more temperate climate than the Gulf, it also draws summer residents from the countries of the Gulf Cooperation Council. Arabs from around the region travel, live, and work in Jordan, making intermarriage a rather common phenomenon, and in response Jordan follows the global pattern of protecting its limited domestic resources by restricting access to citizenship. This limiting makes foreign brides vulnerable to poverty and exclusion following divorce, especially if their natal families are not present in Jordan to advocate for them or support them financially.

Iraqi women faced all of these structural disadvantages in a marriage to a Jordanian during the 1990s, as they do now, and social and economic circumstances in Iraq were also trying during the sanctions period. Women were particularly affected as the Iraqi social system adapted to the oppression and the pressures of dramatic economic deprivation. Marriages in Iraq had tended to follow endogamous patterns prior to that point, but when social and economic circumstances in the country changed, other family configurations became increasingly commonplace. ${ }^{59}$ International sanctions from 1990 to 2003 altered the economy drastically, and kin-making practices were adjusted to reflect the circumstances. ${ }^{60}$ Many families struggled financially during sanctions, and supporting unmarried daughters became an increasingly unsustainable obligation. The population of young men had shrunk due to high casualties during the Iran-Iraq war, increasing competition for husbands and pushing communities to accept suitors who may have been turned away in the past. Marrying outside kin groups became more acceptable as the importance of potential husbands' income went up. Young men living abroad, who could offer a life outside of Iraq, also became more appealing marriage partners. ${ }^{61}$ These shifting priorities in marriage also reflected the closing of paths that had formerly been common for young women, among them predictable marriages within their extended families.

\section{Collateral Damage: Iraqi Divorcees' Social Isolation}

Looking at the various rules and patterns that govern divorced Iraqi women's lives in Amman, it becomes apparent that they are located at the intersection of Iraqi, Jordanian, and international rules, and their attempts to fit into any one category are generally followed by rebuffs on account of association with the other two. Current laws, policies, and social arrangements do not leave a place for Iraqi divorcees, and their sentiments of solitude reflect this impression of falling through the cracks. As discussed above, conflict in Iraq and their Jordanian children both make returning to Iraq and to their parents' homes an unlikely resolution; their children, whose fathers and their extended families remain in Amman as well, make third-country resettlement problematic. The women that participated in this project have all filed for resettlement with the United Nations, and their files are at various points in the process. One has been offered resettlement and passed it up; one has seen her file closed; and the others are simply waiting, as are many other Iraqis. Uniformly, their expectations for resettlement are modest. As one woman, Hana, put it, "I am not going to get resettled ... You just register because maybe once or twice a year they can help you."

If neither staying in Jordan, returning to Iraq, nor resettlement abroad seems particularly hospitable, it may be because none of these avenues appears to have a place for them. Jordanian laws restrict their ability to earn a living without a husband, and the drudgery of day-to-day survival makes a future anywhere seem a long way off. They perceive Iraq as a door that closed behind them when they left, threatening restrictions beyond what they endure in Jordan. Resettlement holds little more than theoretical appeal; reflecting on life outside the Arab world brings up the threat of language barriers and discrimination against Muslims, which often justify shelving the issue entirely, and if this is not enough to dissuade them, the possibility of the children's father's refusal remains as an obstacle. ${ }^{62}$ If women cannot travel with their children to Iraq, then travel to Europe or America or wherever they might be resettled is inconceivable. Doubts that resettlement will ever happen for them keeps the women's commitment to the idea of moving thin. The UN, to them, is as much a centre for collecting 
monthly cash assistance and drumming up extra winter blankets for their children as it is a means toward seeking resettlement.

Dua'a, a 30-year-old mother of two sons, lives in a small apartment in an Amman slum, and most of her time is spent crowded into it alongside her family's belongings. Since there are no cabinets, plastic bags stuffed with clothing and shoes line the walls. Shia from Baghdad, Dua'a moved to Jordan with her parents and siblings in 1999 to escape both persecution and economic hardship. They waited, she told me, until the day after she finished her two-year teaching certificate, but were frightened of what they perceived as the regime's discrimination against Shia, and could not wait long enough for the paper diploma to arrive. After their application for resettlement was rejected by the United Nations, they accepted a marriage proposal for her from their Jordanian neighbour in the hopes that it would lead to a Jordanian residence permit for her and them. In 2002 she was married, and had two sons in two years. She weathered a violent and unstable relationship with her husband until they separated in 2009.

When she and her family left Iraq during the late 1990s, the coincidence of increased educational opportunities for women with a wartime clinging to traditional values meant that divorced women's status became increasingly shameful. "For women, the consequences of divorce do not end with economic insecurity; more significantly, divorced women have to endure social isolation from their families and society," Al-Jawaheri wrote. ${ }^{63}$ Dua'a explained it in different terms:

\footnotetext{
The negatives of Iraqi marriage? ... even if the marriage doesn't turn out well, you have to endure and you have to stay in it. No question. They say to you, forget it, you left your father's house in a white dress and you'll return in a white burial shroud. You have to endure, and divorce or separation is rare. You are patient and you bear the unfairness, even if he turns out to be a bad husband or a bad father, you endure it and you stay committed to your marriage.
}

The high stakes of a union like hers, which not only bound her to her husband and their future children but also carried her and her parents' residence in Jordan in the balance, made her a vulnerable bride. Her disadvantaged position in the Jordanian legal system, where men enjoy a greater share of rights in a marriage contract, further entrenched her vulnerability. Dua'a described herself as unaware when she got married and too young to evaluate her choice properly. Her family also failed to foresee the difficulties she would face. Her marriage and divorce changed their attitudes about intermarriage with Jordanians, she said, and after her experience, they want her sisters to marry Iraqis.

Dua'a's parents and siblings returned to Baghdad in 2006 and she filed for resettlement again on her own after her divorce in 2009. She said that a UN lawyer informed her that while her case was sustainable, her children's applications for resettlement would be difficult. "Why would they give the rights of a refugee to someone who has a national number?" she said, referring to her children's Jordanian citizenship. "It's hard for them." There does not seem to be a way out of Jordan for her, and as a non-Jordanian without a residence permit, the only work available to her is in the informal economy doing manual labour at low wages. The fact that she does not have her teaching certificate in hand makes her ineligible to apply for work as a teacher. Her establishment in Jordan is more of a default arrangement then anything, with her ties to the community staying at a superficial level. "I have a formal relationship with my neighbours," she says. "Hello, hello, that's it." Her learned suspicion of outsiders and her neighbours' chilly reception of a divorced single mother keep relations distant.

I have superficial relationships. I go out, I like to go out, but people, when they come, they want a bigger house, furniture, they want you to take them out, these kinds of things. Me, most of my time is for my kids. Some lectures, and for the kids.

The absence of her husband means financial scarcityhere evoked in the small house, and the inadequate furniture-which compounds the small size of her social circle, and the superficiality of the relationships. The home, where she might normally host guests or visitors, is now something to be kept out of view as well. Dua'a treats life in Jordan as something to be endured, though even the little freedom she has to be left alone may not be available to her in Baghdad. Despite the threadbare nature of her days in Amman, divorcees' reception in Iraq is worse, and she is wholly convinced that ostracism would be waiting for her upon her return. A woman living alone in Jordan struggles, but she perceives life in Iraq as presenting further challenges, which she expresses in these terms:

[In Iraq] They blame the woman for everything. No matter what you've endured already, you have to endure more for the sake of your family. Full stop. ( ... )

Even if there are disagreements, the important thing is you, the woman. No one asks why you waited things out or why you stayed silent, no. And then when divorce happens, no one welcomes the divorcee. She's divorced. Why did he leave her? He's never in the wrong. They don't give her any excuses. She's so-so, no good. 
That's why he left her. Or she can't have kids. Or she doesn't know how to raise her kids. They forget any good qualities that a woman might have. It's a man's world more than a humane world.

Dua'a articulates here the ways that social norms perform the task of discouraging divorce more forcefully than the law could do: a woman who fails to keep her marriage together, regardless of what that entails, sacrifices the regard of her neighbours, and so she usually tolerates as much as she is able. Parents do not always support their divorced daughters; one study participant, Zahra, has never told her family that she is divorced. The perception that Iraqi society is even less forgiving than Jordanian for divorced women adds a further reason not to leave Jordan and head home, but the sensation of being isolated in Jordan and ostracized in Iraq compounds the solitude of the divorced women's experiences.

Herself the daughter of a Jordanian mother and an Iraqi father, Hana now lives in a one-bedroom apartment with her five children. Her husband left them without granting her a formal divorce and now lives in a suburb of Amman with his new wife. For her, being alone in a foreign country means a bitter self-reliance that keeps barriers up between herself and her family as well as her Jordanian hosts.

Hana: Exile is bitter. I'll give you my experience: exile is bitter. It is hard, hard. And their customs here are difficult.

SUSAN: In Jordan?

Hana: Very.

SUSAN: How would you compare Jordanian customs to Iraqi?

HANA: Iraqi customs are harder. Much harder. Jordanians, eh,

somewhat. But the Iraqi customs are much harder. Much harder.

Hana's experiences echo Dua'a's; it is the woman, in both cases, who is expected to carry the burdens of being a wife, and should she divorce it will reflect her failure to do so. In part, relative alienation from the neighbours minimizes the importance of their approval or disapproval. Jordanians, she explained, do not interfere like Iraqis-they can be cold, but they leave one another alone; in this sense, their customs are only somewhat hard. The bitterness of exile that she refers to, then, is tempered with an absence of illusions about the possibilities for returning home, as in fact, the rigidity of Iraqi expectations for women is part of what keeps her in Amman. The fatigue of life in Jordan does not generate nostalgia for life in Iraq; in fact, the opposite: women stay in Jordan because they are acutely aware of what awaits them if they go back.

Hana feels distinctly that when she left her parents' home she left it for the last time. In this sense, Jordan is very much a refuge for her, though it offers only scant comfort.
There were problems between my family and my husband [after we were married]. I couldn't leave my kids and run behind my family because my brothers were married and my parents, how long were they going to live? So to leave my children, and live with my brothers' wives, and let them take me here and there and away from my kids ... it's much better for me to stay in my own house.

$(\ldots)$

It's been four years since he left us, but I feel that this is my kingdom, this house. I ate, drank, went to sleep hungry, went to sleep naked ... no one imposes on me here. With your family, God knows how much time you've spent with your family and how much of your upbringing was with them, but when you get married and go to them, you feel like you've become a foreigner. Tomorrow, you'll get married and you'll feel this feeling. Remember me.

Hana here expresses the finalism of her displacement. Unlike some others, she is not a temporary resident in Jordan merely passing through. At some point, she had the intention of staying, and to return is, in a sense, a regression to her childhood and to a subject position she no longer occupies. Zahra, like Hana, phrases her predicament in terms of social discrimination against divorcees. In her view, all Iraqi-Jordanian marriages were to be regarded skeptically: even if an Iraqi woman is living a good life with her husband here, she told me, you have to wonder how much better things were for her before. The everyday indignities of life as a single mother, such as visiting the school her son attends to speak with the male principal, put her ill at ease. She described running errands more appropriately completed by a husband as embarrassing, marking her as divorced. These everyday trials make her slow to put down roots. Another research participant, Hiba, framed her attitude toward life in Jordan more emphatically: "I don't have any Jordanian friends-My god, they are so prejudiced."

Historical ties between Jordan and Iraq, and personal ties through their children and their in-laws, have not translated into full social integration for these women. Nonetheless, as Iraq remains unstable and life abroad untenable, leaving Jordan seems unrealistic. Thus, they access the minimal benefits available to them, by presenting themselves as refugees if need be.

\section{Refugees or Just Stranded: Challenging Classification}

Entwined in their host society in complex and intimate ways, Iraqi women married to Jordanian men are stranded in Jordan, caught between the violence of their home country and laws in their host country. Their displacement is social, not physical. The fact that they came to Amman 
intending to settle there, rather than intending to move on or return, does not diminish their need for refuge. Dua'a's choice between resettlement and her children and Hiba's three postponements of her flight to the United States indicate that transfer out of Jordan does not suit their needs either. These women struggle against violent conditions in their home country, marriage and immigration laws limited in their regard for women's rights in their host country, and stringent standards for resettlement candidates to third countries, which leaves them a limited range of choices. The long history preceding their predicament indicates a need for more reflection on refugees' integration in host societies and the structural, rather than tangible, violence that gives "displacement" such powerful meaning.

The migration patterns between Iraq and Jordan, and the tendency for Iraqis to marry foreigners during the 1990s and after, mean marriages between Iraqis and Jordanians were not unheard of during those years. ${ }^{64}$ Marriages between Jordanians and other Arab nationalities (e.g. Palestinians, Syrians, Lebanese) are anecdotally common. The attitude of crisis surrounding Iraqis in Jordan is typically attributed to the number of refugees in the country, but their numbers are difficult to ascertain with any confidence and the number tends to shrink every time it is subject to tighter scrutiny. One factor contributing to the crisis proportions of this problem, though, is the use of the refugee funnel as a safety valve for problems that have a domestic element. Iraqi women divorced from Jordanian men are caught in the spiderweb of so many Jordanian institutions, but refugee resettlement remains the most straightforward means of alleviating the challenge they present to the system. The obstacles to their actually leaving speak to the need for a domestically oriented solution.

To call their circumstance the result of a crisis is an incomplete analysis for a situation developed over many years. The number of forcibly displaced people in the world-43.7 million-should suffice to demonstrate that these tragedies happen with enough frequency that continuing to call them "crises," as if they catch the world off-guard, is an inadequate description. ${ }^{65}$ The isolation that the women experience and voice indicates that attention to Iraqis' situation that ignores their isolating experience in Jordan will lead to more discontent, with undetermined consequences.

Evidence from the literature demonstrates how complicated a relationship Jordan maintains with its Arab guests, a problem with roots that predate both the Iraqi refugee crisis and the 1948 and 1967 Palestinian refugee crises. In part because of this complex history, Jordan maintains policies that contribute to Iraqi women's feelings of isolation in their marriages to Jordanians, a sentiment reinforced by tensions between native Jordanians and Iraqi guests. The discourse of "crisis" that surrounds Iraqis' presence in Jordan emphasizes divisions and leaves the political and social connections between Jordan and Iraq to one side. For all the above-mentioned reasons relating to domestic, regional, and international aid politics, the legal absorption of Iraqis as Jordanian citizens seems unlikely. Nevertheless, Iraqis like the women represented here are also unlikely to leave Jordan, and recognizing their ties to Jordan by giving them a legal status in the country could avoid exacerbating divisions between Iraqis and Jordanians unnecessarily.

\section{Notes}

1. Hannah Arendt, "We Refugees," Menorah Journal 31 (January 1943), reprinted in Altogether Elsewhere: Writers on Exile, ed. Marc Robinson (London: Faber and Faber, 1994), 110-9.

2. Janis Jenkins and Michael Hollifield, "Postcoloniality as the Aftermath of Terror Among Vietnamese Refugees," in Postcolonial Disorders, ed. Mary-Jo DelVecchio Good, et al. (Berkeley: University of California Press, 2008), 378-98; Liisa Malkki, Purity and Exile: Violence, Memory, and National Cosmology among Hutu Refugees in Tanzania (Chicago: University of Chicago Press, 1995); Aihwa Ong, "Cultural Citizenship as Subject-Making: Immigrants Negotiate Racial and Cultural Boundaries in the United States," Current Anthropology 37, no. 5 (December 1996): 737-62.

3. Steven Vertovec, "The Cultural Politics of Nation and Migration," Annual Review of Anthropology 40 (2011): 241-56.

4. Malkki, Purity and Exile.

5. Didier Fassin, "The Vanishing Truth of Refugees" (presented at the Annual Elizabeth Colson Lecture, Refugee Studies Centre, Oxford, June 15, 2011).

6. Didier Fassin and Richard Rechtman, The Empire of Trauma: An Inquiry into the Condition of Victimhood (Oxford: Princeton University Press, 2009); Miriam Ticktin, "Where Ethics and Politics Meet: The Violence of Humanitarianism in France," American Ethnologist 33, no. 1 (2006): 33-49.

7. Ong, "Cultural Citizenship as Subject-Making."

8. Fassin and Rechtman, The Empire of Trauma.

9. Emma Haddad, The Refugee in International Society: Between Sovereigns (Cambridge: Cambridge University Press, 2008).

10. Ibid.

11. Stephen J. Collier and Aihwa Ong, "Global Assemblages, Anthropological Problems," Global Assemblages: Technology, Politics and Ethics as Anthropological Problems, ed. Collier and Ong (Oxford: Blackwell Publishing, 2005); Aihwa Ong, "Mutations in Citizenship," Theory, Culture, and Society 23, no. 2-3 (May 2006): 499-505. 
12. Suad Joseph, "Gendering Citizenship in the Middle East," Gender and Citizenship in the Middle East, ed. Joseph, 3-30 (New York: Syracuse University Press, 2000), 3.

13. Valentine Moghadam, "Introduction and Overview," Gender and National Identity: Women and Politics in Muslim Societies, ed. Moghadam (London: Zed Books, 1994), $1-13$.

14. Deniz Kandiyoti, "Introduction," in Women, Islam and the State, ed. Kandiyoti (Philadelphia: Temple University Press, 1991), 1-21.

15. "Memorandum of Understanding Between the Government of Jordan and UNHCR," UNHCR RefWorld (UN High Commissioner for Refugees, April 5, 1998), accessed 23 August 2008, http://www.unhcr.org/refworld/ docid/3ae6b31920.html.

16. Clifford Geertz, "Thick Description: Toward an Interpretive Theory of Culture," in Geertz, The Interpretation of Cultures (New York: Basic Books, 1973), 3-30.

17. Paul Dresch, "Wilderness of Mirrors: Truth and Vulnerability in Middle Eastern Fieldwork," Anthropologists in a Wider World: Essays on Field Research, ed. Dresch et al. (Oxford: Berghahn Books, 2000).

18. E. Valentine Daniel and John Chr. Knudsen, "Introduction," in Mistrusting Refugees, ed. Daniel et al. (Berkeley: University of California Press, 1995); Fassin, "The Vanishing Truth of Refugees".

19. Joseph Sassoon, The Iraqi Refugees: The New Crisis in the Middle East (London: I. B. Tauris, 2009); Ann Scott Tyson, "Iraqi Refugee Crisis Seen Deepening." Washington Post, January 17, 2007.

20. Iraqis can establish legal status in the country through investor status, residency permits, or stay permits; all of these avenues have an associated cost, making them out of reach for lower-income Iraqis like the women with whom I worked. For further explanation of the different statuses and how they are awarded, see Mohamed Olwan, "Iraqi Refugees in Jordan: Legal Perspective" (Florence: CARIMEuro-Mediterranean Consortium for Applied Research on International Migration, 2009).

21. Kamal Salibi, The Modern History of Jordan. 2nd ed. (London: I.B. Tauris, 1998).

22. Joseph Massad, Colonial Effects: The Making of National Identity in Jordan (New York: Columbia University Press, 2001).

23. Ibid.

24. Michel Foucault, "Governmentality", in The Foucault Effect: Studies in Governmentality, with Two Lectures and an Interview with Michel Foucault, ed. Graham Burchell, et al. (Chicago: University of Chicago Press, 1991).

25. Refugee status is not granted by the Jordanian government, though it does grant a six-month resettlement window to Iraqis recognized as refugees in 1998 MOU with UNHCR. Beyond that time, Iraqis are considered "guests." Conversationally, the word "refugee" has a more layered meaning than just a legal status. My observation was that service organizations used the term interchangeably with Iraqis, thus framing a population in need; this may have changed between the drafting of this article and its publication following the arrival of large numbers of Syrians. Some Jordanians, also, would use the term to refer to all Iraqis; sometimes when I remarked that I was doing research with Iraqi refugees, I was told that I would be likely to meet them at restaurants and shopping malls-a reference to the wealthy Iraqi community now resident in Amman, who in most cases neither have refugee status with UNHCR nor self-identify as refugees. Clearly the term carries social significance beyond simply indicating a registration status.

26. Anthony Cordesman and Ahmed Hashim, Iraq: Sanctions and Beyond (Boulder, CO: Westview Press, 1997); Géraldine Chatelard, "Deferred Involvement: Memories and Praxes of Iraqi Intellectuals as Civil-Society Activists between Iraq, Jordan and Syria" (paper presented at Memories of Iraq, University of Maryland, College Park, MD, 2009); Géraldine Chatelard, "What Visibility Conceals: Reembedding Refugee Migration from Iraq," Dispossession and Displacement: Forced Migration in the Middle East and North Africa, ed. Chatty et al. (Oxford: Oxford University Press, 2010).

27. Yasmin H. Al-Jawaheri, Women in Iraq: The Gender Impact of International Sanctions (Colorado: Lynne Rienner Publishers, 2008), 7

28. United States Committee for Refugees and Immigrants, "U.S. Committee for Refugees World Refugee Survey 1997Jordan" (January 1, 1997), accessed 2 August 2012, http:// www.unhcr.org/refworld/docid/3ae6a8ba38.html.

29. Chatelard, "What Visibility Conceals."

30. Géraldine Chatelard, "Cross-Border Mobility of Iraqi Refugees," Forced Migration Review 34 (February 2010): 60-61.

31. Chatelard, "What Visibility Conceals."

32. Géraldine Chatelard, "Jordan's Transient Iraqi Guests: Transnational Dynamics and National Agenda," in Viewpoints: Special Edition on Iraq's Refugee and IDP Crisis (Washington, DC: Middle East Institute, 2008): 20-22; Dawn Chatty and Philip Marfleet, "Iraq's Refugees: Beyond Tolerance," (Forced Migration Policy Briefing 4, Refugee Studies Centre, Oxford, 2009); "Iraqis in Jordan 2007: Their Number and Characteristics" (Amman, Jordan: Fafo and the Government of Jordan, 2008); International Rescue Committee, "Iraqi Displacement: Eight Years Later Durable Solutions Still Out of Reach" (New York: International Rescue Committee, 2011); Joseph Sassoon, The Iraqi Refugees.

33. Nadje Al-Ali and Nicola Pratt, "Women in Iraq: Beyond the Rhetoric" Middle East Report (MERIP) 239 (June 2006): 18-23; Nadje Al-Ali and Nicola Christine Pratt, What Kind of Liberation? Women and the Occupation of Iraq (Berkeley: University of California Press, 2009); "Iraq 2012 Regional Response Plan" (UNHCR, 2011).

34. "Response to Information Requests, Jordan: Whether a Jordanian Woman Needs Her Husband's Permission to Leave 
Jordan, Et Cetera" (Immigration and Refugee Board of Canada, 2005), accessed 2 August 2012, http://www.irb-cisr .gc.ca:8080/RIR_RDI/RIR_RDI.aspx?l=e\&id=428471.

35. The terms of the $1998 \mathrm{MOU}$ give UN-recognized refugees six months' clearance to reside in the country, after which they are technically in the country illegally. See UNHCR, Memorandum between UNHCR and the Government of Jordan.

36. Shane Bauer, "Most Iraqi Refugees Still Unwilling to Return, Even for Money," New American Media, Damascus, October 31, 2008; Mark MacKinnon, "Jordan and Syria Tighten Borders for Iraqi Refugees," Toronto Globe and Mail, Amman, September 17, 2007; Samia Qumri, “Iraq's Refugees in Jordan Live in Desperate Limbo," Women's E-News, Amman, April 19, 2012.

37. Géraldine Chatelard, "Jordan: A Refugee Haven" (Washington, DC: Migration Policy Institute, August 2010), accessed 2 August 2012, http://www.migrationinformation .org/feature/display.cfm? ID=794.

38. The full text of the 1951 Convention describes a refugee as someone who, "owing to well-founded fear of being persecuted for reasons of race, religion, nationality, membership of a particular social group or political opinion, is outside the country of his nationality and is unable or, owing to such fear, is unwilling to avail himself of the protection of that country; or who, not having a nationality and being outside the country of his former habitual residence as a result of such events, is unable or, owing to such fear, is unwilling to return to it". See "Convention Relating to the Status of Refugees" (Office of the United Nations High Commissioner for Human Rights, July 28, 1951), accessed 2 August, 2012, http://www2.ohchr.org/english/law/refugees .htm.

39. UNHCR, Memorandum between UNHCR and the Government of Jordan.

40. Olwan, "Iraqi Refugees in Jordan."

41. Jordan Department of Statistics, "13.1 percent the unemployment rate during the first quarter of 2011" (Amman: Government of Jordan, 2011).

42. As of 2011, 60,000 Iraqis had departed for third countries out of an estimated 2 million refugees; this represents about 23 percent of those who had registered for resettlement. Chatelard, "From Humanitarian Intervention to Durable Solutions" (Washington, DC: Middle East Institute, 2011), accessed 2 August, 2012, http://www.refugeecooperation .org/publications/Iraq/09_chatelard.php.

43. "Iraq 2012 Regional Response Plan" (UNHCR, 2011); "UNHCR Poll: Iraqi Refugees Reluctant to Return to Iraq Permanently” (UNHCR, October 8, 2010); Confronting Poverty in Iraq (World Bank, January 2010).

44. UN Habitat, Urban Baghdad: Impact of Conflict on Daily Life (Nairobi: UN Habitat, 2010).

45. Central Organization for Statistics and Information Technology Iraq, et al., "Comprehensive Food Security and
Vulnerability Analysis," United Nations World Food Programme (Rome: UNWFP, 2008).

46. "Social Trends in Jordan" (Jordan Department of Statistics, 2006).

47. "Amid Economic Hardships, Jordan's Divorce Rate Rising," Jordan Times, August 14, 2008.

48. Ibtesam Alatiyat and Hassan Barari, "Liberating Women with Islam? The Islamists and Women's Issues in Jordan," Totalitarian Movements and Political Religions 11, no. 3-4 (2010): 359-78.

49. Massad, Colonial Effects; Amira El-Azhary Sonbol, "The Woman Follows the Nationality of Her Husband': Guardianship, Citizenship and Gender," Hawwa 1, no. 1 (2003).

50. Human Rights Watch, "Stateless Again: Palestinian-Origin Jordanians Deprived of Their Nationality" (New York: Human Rights Watch, 2010); Rana Husseini, "Citizenship for Jordanian Women's Spouses Key to Familial Tranquility," Jordan Times, December 12, 2010; Naseem Tarawneh, "Foreigners in Their Own Land: Jordanian Women and Hereditary Citizenship," The Black Iris, December 28, 2007.

51. Ziba Mir-Hosseini, "The Construction of Gender in Islamic Legal Thought and Strategies for Reform," Hawwa 1, no 1 (2003). Mir-Hosseini contests the idea that sharia in its purest form discriminates against women, but notes that in practice legal codes derived from it consistently offer men more protection.

52. Nikki Keddie, "The Past and Present of Women in the Muslim World," Journal of World History 1, no. 1 (Spring 1990): 77-108.

53. H. Hamamy, L. Jamhawi, J. Al-Darawsheh, and K. Ajlouni, "Consanguineous Marriages in Jordan: Why Is the Rate Changing with Time?" Clinical Genetics 67 (2005): 511-16; S. A. Khoury and D. Massad, "Consanguineous Marriage in Jordan," American Journal of Medical Genetics 43 (1992): 769-75.

54. Massad, Colonial Effects; Sonbol, "The Woman Follows the Citizenship of the Husband."

55. Suad Joseph, "Gendering Citizenship in the Middle East," in Gender and Citizenship in the Middle East, ed. Joseph (New York: Syracuse University Press, 2000), 3-30; Deniz Kandiyoti, "Introduction," in Women, Islam and the State, ed. Kandiyoti (Philadelphia: Temple University Press, 1991), 1-21; Valentine Moghadam, "Introduction and Overview, in Gender and National Identity: Women and Politics in Muslim Societies, ed. Moghadam (London: Zed Books, 1994), 1-13.

56. Laurie Brand, Jordan's Inter-Arab Relations: The Political Economy of Alliance Making (New York: Columbia University Press, 1995).

57. Richard Antoun, Documenting Transnational Migration: Jordanian Men Working and Studying in Europe, Asia and North America (Oxford: Berghahn Books, 2005); Géraldine Chatelard, "Jordan: A Refugee Haven" (Migration Policy Institute, August 2010). 
58. International Organization for Migration, "World Migration Report 2008: Middle East” (IOM, 2008); International Organization for Migration, "World Migration Report 2010: The Future of Migration: Building Capacities for Change" (IOM, 2010).

59. Al-Jawaheri, Women in Iraq; Dale Eickleman, The Middle East: An Anthropological Approach (Upper Saddle River, New Jersey: Prentice Hall, 1989); Ernest Main, Iraq: From Mandate to Independence. 2nd ed. (London: Kegan Paul, 2004).

60. Al-Jawaheri, Women in Iraq.
61. Ibid.
62. "Response to Information Requests, Jordan."
63. Al-Jawaheri, Women in Iraq, 105.
64. Al-Jawaheri, Women in Iraq.
65. UNHCR, Global Trends 2010 (UNHCR, 2010).

Susan MacDougall is a graduate student in social anthropology at Oxford University. 